\title{
More on Mechanics Liens, Stop Notices and the Like
}

\author{
Charles E. Goulden* and Larry Braxton Dent**
}

$\mathbf{M}^{1}$

ECHANICS LIENS and stop notices are statutory, nonconsensual security devices which concern the construction industry." "Mechanic" is used in its older sense to refer to "laborers" or "workmen." A laborer or workman, however, seldom files a mechamics lien, ${ }^{3}$ so when the word "mechanic" is used it really concerns building contractors, subcontractors, and materialmen. A good definition is: "A mechanics" lien is a charge imposed upon specific real property as security for the remuneration of those who have contributed labor or materials to the inprovement of the property." The stop notice also is a security device, available to nembers of the construction industry other than prime contractors, ${ }^{5}$ with no relationship to mechanics hens other than certain procedural ties. The stop notice is a lien against construction fumds rather than the improvenient. ${ }^{6}$

This article is concerned exclusively with the operation of mechanics liens and stop notices within the sphere of private, nongovernmental works of improvement in California. The first two sections discuss the current law and nethods by which lenders and owners inay protect themselves from adverse effects associated with mechanics liens and stop notices. The third section discusses proposed legislation.

For the benefit of those who are not familiar with the jargon of the construction industry, and for those who are but attribute to words meanings different from those intended by this article, the following definitions may be helpful:

Improver: Any person who provides goods or services to or for the construction of an improvenient to real property.

Lender: A third party who lends money for the construction of

* Member, State Bar of California; Bar Association of San Francisco.

** Member, California Law Revieve.

1 The state constitution provides for the lien, CAL. Const. art. XX, $\$ 15$, but the constitutional provision is not self-executing and must be supplemented by legislative action. Spinney v. Griffth, 98 Cal. 149, 32 Pac. 974 (1893). The relevant statutes are contained in $\$ \S 1181-1203.1$ of the Code of Civil Procedure.

2 Comment, 51 Carir. L. Rev. 331 n.2 (1963).

3 Id. at 361 n.228; Comment, 16 HAstivgs L.J. 198, 204-05 (1964).

4 Comment, 51 Carif. L. Rev. 331 (1963) (footnotes omitted); see CaI. Code Civ. Proc. $\$ \S 1180,1181,1184.1$.

5 CAL. Code Civ. Proc. $\S \S 1190.1-92.2$.

${ }^{6}$ See generally Comment, 51 CALIF. L. Rev. 331, 351-54 (1963). 
an improvement to real property. This usually is an "institutional lender" such as a bank or savings association.

Owner: The person who contracts for the construction of an improvement to real property.

Prime Contractor: An improver who contracts directly with the owner. There may be more than one prime contractor on a given job, as when the owner contracts directly with specialty contractors.

Secondary Improver: An improver who contracts with a prime contractor or other secondary improver and who is entitled to perfect a mechanics lien.

This article assumes some familiarity with the subject on the part of the reader. ${ }^{7}$ The general field has been treated adequately elsewhere. ${ }^{8}$ When coping with the statutes, it is best not to rely on common sense; instead, the subject requires adherence to the myriad rules that have been established. One generalization may be made: Application of the existing rules uniformly works to the disadvantage of the owner.

THE DEVICES

Apart from ordinary contract remedies, the California improver has three security devices at his disposal to obtain payment for labor or materials furnished in connection with a private construction projectthe mechanics lien, the equitable hen, and the stop notice.

\section{A. Mechanics Liens}

Mechanics hen statutes have the effect of making the owner an involuntary guarantor of payment to the prime contractor and all secondary improvers. The owner assures secondary improvers the reasonable value of the labor or materials they have furnished, without regard to

7 The entire statutory system of mechanics liens and stop notices has been exposed to critical review in recent years. See, e.g., State Bar of California, Final Report of Committee to Study 1958 Conference Resolution No. 70, September 11, 1962 (unpublished report in University of California Law School Library, Berkeley); California Mechanics' Liens, 16 HAsInNGs L.J. 149 (1964) (entire issue devoted to various aspects of subject); Crocker, Stop Notice Problems of Institutional Lenders, 40 Los Avgetes Bar Bull. 323 (1965); Hopkins, Stop Notices-Latest Report from the Battlefront, in CarIforNa LaND Titie Ass's, Proceedings Fifty-ergetr Annual Convention 62 (1965); Comment, 51 CAIF. L. REv. 331 (1963); Mechanics Liens: Just What Is Your Hazard?, Sunset, July, 1963, p. 92 ; Address by J. L. Kalbach, standards chairman of D. G. Corp., First Conference, Oakland, California, March 4, 1965.

8 Comment, 51 CALIF. I. Rev. 331 (1963). See generally Minter \& Starr, Current LaW of Cartrordia ReAL Estate ch. VIII (1965) (written primarily for real estate brokers). For forms and other practical information, see MarsH, Calrfornda MeCHantcs' LIEN LaW HANDBOOK (1965). 
the prime contract price (unless the prime contract and a bond were recorded).$^{9}$ In the absence of a contract directly with the improver, the owner is not personally liable, ${ }^{10}$ but the improvement and, to an extent, the land upon which the improvement is situated are hypothecated by law to improvers entitled to liens. ${ }^{11}$ Of course, the owner may not be an effective surety if his property is fully encumbered by security devices that have priority over mechanics liens. ${ }^{12}$

\section{Perfecting the Security Device}

The unpaid improver first must determine whether he is entitled to a mechanics lien and, if he is, then comply with the rules for perfecting and enforcing the lien. In broad terms, the improver is entitled to a mechanics lien only if he has contributed to a work of improvement pursuant to a valid contract with the owner. ${ }^{13}$ Establishing the existence of a contract with the owner is easier than it might sound and certainly requires no cooperation fron the owner, for the owner-by law-has

${ }^{\circ} \mathrm{CAL}$. Code CIv. Proc. $\S$ 1185.1. The secondary improver is not, however, entitled to recover more than the amount for which he contracted. CaL. Code Crv. Proc. \& 1185.1(a). The owner may limit his hability to his contract price with the prime contractor by recording the prime contract and a labor and materials payment bond before work is commenced. The bond must be for an amount not less than fifty per cent of the contract price and must inure to the benefit of all persons performing labor upon or furnishing materials to the work of improvement. CAL. CODE Crv. Proc. $\$ 1185.1$ (c).

10 Golden Gate Bldg. Materials Co. v. Fireman, 205 Cal. 174, 270 Pac. 214 (1928); Roberts v. Security Trust \& Sav. Bank, 196 Cal. 557, 238 Pac. 673 (1925); Stockton Lumber Co. v. Schuler, 155 Cal. 411, 101 Pac. 307 (1909); Mott v. Wright, 43 Cal. App. 21, 184 Pac. 517 (1919); Los Angeles Pressed Brick Co. v. Higgins, 8 Cal. App. 514, 97 Pac. 414 (1908). See also text accompanying notes 50-66 infra.

11 The present statutory lien system provides for two separate kinds of hens. Improvers who make direct contributions to a building or other structural work of improvement "shall lave a hen upon the property upon which they have bestowed labor or furnished materials," Car. Cone Crv. Proc. $\$ 1181$, and upon a limited portion of the land if "the land belonged to the person who caused said building . . . or structure to be constructed . . . . CAI. CODE Civ. Proc. $\$ 1183.1$.

The second type of lien secures payment for nonstructural and offsite improvements, such as sidewalks and sewers, by allowing "a hen upon said lot or tract of land" with which the improvements are connected. CaL. Code Crv. Proc. § 1184.1; Comment, 51 CaIIF. L. REv. 331, 348-51 (1963).

12 As a general rule the deed of trust held by a lender or other party will have priority over mechanics hens if the deed of trust was recorded prior to the time the work of improvement first was commenced. CAI. Code Crv. Proc. $\S 1188.1$; Comment, 51 CaIIF. L. REV. 331, 348-51 (1963).

13 Comment, 51 CAIFr. L. REv. 331, 333-36 (1963). This article is not concerned with the problems attendant upon determining whether there was a contribution to a work of improvement.

An express trust fund established pursuant to a collective bargaining agreement has a lien in some circumstances for the amount of the supplemental fringe benefits due under the collective agreement. CAL. Code CIV. Proc. § 1182(d). 
an indeterminate number of agents with full authority to hypothecate the property. ${ }^{14}$

(a) Statutory Agency.-The California mechanics lien is "direct" in that the claimant's lien arises directly from his contract with the owner or the owner's agent. ${ }^{15}$ The contractual relationship between the owner and the prime contractor is clear, since the two entered into an agreement. The contractual relationship between the owner and secondary improvers is achieved through the medium of statutory agency articulated in section 1182(c) of the Code of Civil Procedure: "For the purposes of this chapter, every contractor, subcontractor, architect, builder, or other person having charge of the construction, alteration, addition to, or repair, in whole or in part of any building or other work of improvement shall be held to be the agent of the owner." In determining the persons who are agents of the owner for purposes of mechanics liens, the state supreme court in Theisen v. County of Los Angeles ${ }^{16}$ read section 1182 (c) literally. Theisen held that the test of a "subcontractor" is whether, "in the course of performance of the prime contract he constructs a definite, substantial part of the work of improvement in accord with the plans and specifications of such contract ...."17

It should be noted that the Theisen definition of "subcontractor" has nothing to do with the hierarchy on a construction project. If a prime contractor is one who contracts with the owner, then a subcontractor is one who contracts with the prime contractor. One who contracts with a subcontractor would be a sub-subcontractor and so on, down the line. But if sub-subcontractors and the like meet the Theisen test, then for purposes of inechamics liens they are "subcontractors" and therefore statutory agents. Parties who deal with them are entitled to a lien.

Since section 1182 (c) pertains not only to the enunciated classes but also to every "other person," the Theisen definition of "subcontractor" is irrelevant for all practical purposes. Any person who meets the Theisen test is a statutory agent, so that anyone who contracts with him has inet the mechanics lien requirement of having entered into a contract with the owner.

It is apparent that there may be a considerable number of statutory agents involved in any construction project. Whether somebody is a statutory agent is a question of fact. ${ }^{18}$ In determining whether the work

${ }^{14}$ See note 59 infra and accompanying text.

15 See Cax. Code Civ. Proc. § 1185.1 (a); 68 YATE L.J. 138, 144 (1958).

1654 Cal. 2d 170, 352 P.2d 529, 5 Cal. Rptr. 161 (1960).

17 Id. at 183,352 P.2d at 537,5 Cal. Rptr. at 169.

${ }^{18}$ See Piping Specialties Co. v. Kentile, Inc., 229 Cal. App. 2d 586, 40 Cal. Rptr. 537 (1964). Piping Specialties held that a materialman who supplied items that were not uniquely designed for the particular job had not performed work "in accord with the 
is "substantial" under the Theisen test, dollar values are not determinative; the test is whether the work was "important" or "material."19

(b) Procedural Requirements for Perfecting the Lien.-Improvers must comply with stringent procedural requirements in order to perfect their lien rights. Applicable time limits depend upon the status of the construction project, upon acts of the owner, and upon whether the improver is a prime contractor or a secondary improver.

(i) Completed Construction Projects.- When the owner does nothing, the prime contractor and secondary improvers have ninety days after a project is completed to perfect claims of lien by recordation. ${ }^{20}$ The prime contractor must have completed his contract before he records the claim of hen. ${ }^{21}$ Secondary improvers must have ceased to perform labor or furnish materials ${ }^{22}$ and must give at least fifteen days' notice to the owner and to the prime contractor before recording the claim of lien. ${ }^{23}$

The owner may sliorten the time within which claims of lien may be recorded by himself recording a "notice of completion."24 When the improvement is constructed pursuant to a single origmal contract, recording the notice of completion limits the recordation period to sixty days for prime contractors and thirty days for secondary improvers from the date the notice of completion was recorded. ${ }^{25}$ When the improvement is constructed pursuant to two or nore origiral contracts, each of which pertains to a particular portion of the improvement, the owner may file a notice of completion for the improvement contemplated by each separate contract. ${ }^{20}$ The notice of completion then limits the time within which hens may be recorded to sixty days for the prime contractor and thirty

plans and specifications." Id. at 589-90, 40 Cal. Rptr. at 539. It is too early to determine the ease with which appellate courts will find statutory agency.

19 Id. at 588-89, 40 Cal. Rptr. at 539.

20 Car. Code Crv. Proc. § 1193.1 (c).

21 Cax. Code Crv. Proc. \$ 1193.1 (a).

22 Ibid.

23 CAI. CODE Crv. Proc. § 1193. The statute exempts persons under direct contract with the owner or performing actual labor for wages from the pre-lien notice requirements.

The notice must contain specified information and be served in accordance with the requirements of the statute. The notice need not, however, describe the property against which the lien is to be asserted. Borello v. Eichler Homes, 221 Cal. App. 2d 487, 491, 34 Cal. Rptr. 648, 651 (1963). A recent case held that an owner (whose lessee liad contracted for the improvements) who fails to give the notice of nonresponsibility required by $\$ 1183.1(\mathrm{~b})$ is "under direct contract" with a secondary improver and need not be served with the fifteen-day pre-lien notice under $\S 1193$. Halspar, Inc. v. La Barthe, 238 A.C.A. 1020, 48 Cal. Rptr. 293 (1965). The case is a good example of the way in which an absurd result is reached through a pseudo-logical application of the statutes.

24 CAI. Code Crv. Proc. \& 1193.1(c). The notice of completion must contain the information specified in $\S 1193.1(\mathrm{f})$ of the Code of Civil Procedure.

25 CaI. Code Crv. Proc. \& 1193.1(c).

28 CAL. Code Crv. Proc. \& 1193.1(b). 
days for secondary improvers with respect to the portion of the improvement covered by the notice. ${ }^{27}$

In order to be effective, the notice of completion must be filed within ten days after the improvement is completed.$^{28}$ Completion may be actual or constructive. ${ }^{2 \theta}$ If the project is actually completed and the owner fails to file a notice of completion within ten days, then he may not use the constructive completion provisions or the cessation of labor provisions to shorten the period for filmg liens. ${ }^{30}$

(ii) Uncompleted Construction Projects.-If the project is not completed but there is a cessation of labor and the owner does nothing, then the prime contractor and secondary improvers may record claims of lien within the nimety-day period following sixty days of continuous cessation of work..$^{31}$ The owner may shorten this period by recording $a$ "notice of cessation." The notice may be recorded only after work on the improvement lias started and stopped, and labor has ceased for a continuous period of thirty days or more. ${ }^{32}$ The time within which liens may be recorded then is limited to sixty days for the prime contractor and thirty days for secondary improvers from the date the notice was recorded. ${ }^{33}$

(c) Substantial Compliance with Requirements.-Since the requirements for perfecting a lien are somewhat technical, there are bound to be instances in which the improver has not complied with all of the conditions prescribed by statute. When this liappens, the courts are faced with a conflict that often arises in the mechanics lien area. The state constitution provides that improvers slall have a lien; ${ }^{34}$ the mechanics lien statutes fulfill this constitutional mandate by providing financial

27 Ibid.

28 Car. Code Civ. Proc. \$ 1193.1(c).

20 Car. Code CIv. Proc. \$ 1193.1(d). This section provides that any of the following shall be the equivalent of completion: (1) occupation or use by the owner where there has been a cessation of labor; (2) acceptance by the owner; or (3) cessation of labor for a continuous period of sixty days, or for a continuous period of thirty days or more if a notice of cessation is filed. Constructive completion resulting from cessation of labor is governed by $\S 1193.1(\mathrm{~g})$, however. CAL. CODE CIv. Proc. $\$ 1193.1(\mathrm{~d})$. Thus, as far as mechanics liens are concerned, constructive completion resulting from cessation of labor in effect is not regarded as completion and is to be considered as a special problem under $\$ 1193.1(\mathrm{~g})$.

30 Southwest Paving Co. v. Stone Hills, 206 Cal. App. 2d 548, 554, 24 Cal. Rptr. 48, 51 (1962); Mott v. Wright, 43 Cal. App. 21, 26, 184 Pac. 517, 520 (1919).

31 Cal. Code Crv. Proc. \& 1193.1 (g).

32 Ibid. The notice of cessation must be recorded with the county recorder in the county in which the property is situated, must be signed and verified by the owner or his agent, and must contain certain specified mformation. CaL. CODE Crv. Proc. $\$ 1193.1(\mathrm{~h})$. 33 Cax. Code Crv. Proc. § 1193.1(g).

34 Cax. Const. art. XX, $\$ 15$. 
security for improvers. ${ }^{35}$ But to the extent that the mechamics lien statutes force an owner to pay more than he had agreed to pay, or to pay his debt twice, the statutes are highly penal and are to be construed strictly against the improver ${ }^{36}$ this construction may conflict with the constitutional command. The conflict could be resolved most simply by construing the statutes in favor of improvers until the facts were such that a penalty would be visited on the owner; the statutes then would be construed against the improver. The trouble with this approach is that the manner in which the statutes would be construed would be unknown until the economics of the job had been determined. The courts have resolved the conflict by ignormg it and instead looking to the type of error that was made.

As long as there is substantial compliance with the notice requirements and no one is prejudiced by the error, the hen will be sustained, ${ }^{37}$ since the purpose of the claim of hen and of other notices imparting information is to give constructive notice that a lien is claimed. ${ }^{38} \mathrm{Al}$ though by statute a lien is forfeited if the amount of the claim is willfully misstated, ${ }^{39}$ even a misstatement of amount will not invalidate a lien in the absence of clear and convincing evidence that the violation was willful and intentional..$^{40}$ Totally ormitting an essential element of a

35 See Steinbrenner v. J. A. Waterbury Constr. Co., 212 Cal. App. 2d 661, 666, 28 Cal. Rptr. 204, 207 (1963); Ingersoll v. Chaplin, 127 CaI. App. 290, 15 P.2d 790 (1932).

86 Hampton v. Christensen, 148 Cal. 729, 733-34, 84 Pac. 200, 201 (1906); West Coast Lumber Co. v. Knapp, 122 Cal. 79, 54 Pac. 533 (1898); California Portland Cement Co. v. Wentworth Hotel Co., 16 Cal. App. 692, 704, 118 Pac. 103, 113 (1911); cf. Los Angeles Pressed Brick Co. v. Higgins, 8 Cal. App. 514, 97 Pac. 414 (1908).

37 See Wand Corp. v. San Gabriel Valley Lumber Co., 236 A.C.A. 981, 46 Cal. Rptr. 486 (1965); Patten \& Davies Lumber Co. v. Hayden, 113 Cal. App. 103, 298 Pac. 129 (1931); cf. California Elec. Supply Co. v. United Pac. Life Ins. Co., 227 Cal. App. 2d 138, 38 Cal. Rptr. 479 (1964). But see Santa Monica Lumber \& Mill Co. v. Hege, 119 Cal. 376,51 Pac. 555 (1897). Errors in the description of the property may be disregarded provided there is sufficient identification to prevent anyone from being misled. Borello $v$. Eichler Homes, Inc., 221 Cal. App. 2d 487, 492, 34 Cal. Rptr. 648, 652 (1963).

38 The claim of lien is not invalidated if the improver errs in naming the owner as long as there is no intent to deceive and no one was misled to his detriment. Ingersoll v. Chaplin, 127 Cal. App. 290, 15 P.2d 790 (1932) (claim of lien named husband as owner instead of husband and wife). When the owner was not misled, a lien was not invalidated when the claim of lien stated that the general contractor was an individual doing business under a fictitious name while in reality the general contractor was a corporation. Hanlnıond Luinber Co. v. Richardson, 94 Cal. App. 119, 270 Pac. 751 (1928).

39 CAd. Code Crv. Proc. $\$ 1193.1(\mathrm{k})$. There is a similar provision for stop notices. Cat. Code Crv. Proc. $\$ 1190.1(\mathrm{e})$.

40 Callalian v. Chatsworth Park, Inc., 204 Cal. App. 2d 597, 22 Cal. Rptr. 606 (1962); California Portland Cement Co. v. Wentworth Hotel Co., 16 Cal. App. 692, 118 Pac. 103 (1911). Unless there is intent to defraud, any error falls within $\S 1196.1$. Los Angeles Bd. of Adjusters v. Bailes, 116 Cal. App. 316, 2 P.2d 557 (1931). Contra, Santa Monica Lunber 
claim of lien may result in unenforceability, however. ${ }^{41}$ Presumably total omission does not provide constructive conmunication.

The time limits are enforced much more strictly than the informational provisions. A claim of lien filed prematurely confers no lien rights. ${ }^{42}$ Failure to file within the specified time limits after completion or cessation precludes the assertion of an enforceable hen. ${ }^{43}$

\section{Enforcing the Security Device}

(a) Procedural Requirements.-A perfected mechanics hen is enforced by an action for a foreclosure judgment and a judicial sale. ${ }^{44}$ Foreclosure proceedings must be commenced within ninety days after the claim of hen was perfected by recordation. ${ }^{45}$ The time within which suit must be commenced may be extended for a period not exceeding one year when credit is extended to the owner, provided that notice of the extension of credit and the terms of such credit are recorded after the lien was recorded but before the ninety-day period has elapsed. ${ }^{40}$ The court may dismiss a foreclosure action on the perfected lien unless brought to trial within two years. ${ }^{47} \mathrm{~A}$ notice of lis pendens may be recorded after the complaint has been filed. ${ }^{48}$

\& Mill Co. v. Hege, 119 Cal. 376, 51 Pac. 555 (1897). Apparently the owner has the burden of proof on issues of fraud and actual prejudice. Sec Wand Corp. v. San Gabriel Valley Lumber Co., 236 A.C.A. 981, 46 Cal. Rptr. 486 (1965).

41 McCreary v. Toronto Midway Oil Co., 38 Cal. App. 17, 175 Pac. 87 (1918).

42 Marchant v. Hayes, 120 Cal. 137, 52 Pac. 154 (1898); Santa Monica Lumber \& Mill Co. v. Hege, 119 Cal. 376, 51 Pac. 555 (1897); Davis v. MacDonough, 109 Cal. 547, 42 Pac. 450 (1895); McCreary v. Toronto Midway Oil Co., 38 Cal. App. 17, 175 Pac. 87 (1918). The prime contractor may not record his lien until "the completion of his contract" and secondary improvers may not record until they have "ceased to perform labor or furnish material, or both." CAL. CODE Crv. Proc. $\S 1193.1$ (a). In the absence of evidence to the contrary, a court will not assume that materials were furnished after the claim of lien was filed when this would lave the result of invalidating the lien. Ingersoll v. Chaplin, 127 Cal. App. 290, 15 P.2d 790 (1932).

43 Althougl completion is a question of fact, "trivial imperfections" are to be disregarded in determining when the improvement was completed. Santa Monica Lumber \& Mill Co. v. Hege, 119 Cal. 376, 378-79, 51 Pac. 555, 556 (1897); Battersby v. Shepard, 89 Cal. App. 756, 265 Pac. 506 (1928); Hickman v. Freiermuth, 21 Cal. App. 629, 132 Pac. 772 (1913). Actual completion of the improvement (or constructive completion under $\$ 1193.1(\mathrm{~d})$ ) actuates the time periods for recording claims of lien. Jones v. Kruse, 138 Cal. 613, 72 Pac. 146 (1903); Battersby v. Shepard, supra.

44 CaL. Code Crv. Proc. $\$ \S 684,1198.1,1201.1$; see Withington v. Shay, 47 Cal. App. 2d 68, 117 P.2d 415 (1941).

45 Cad. Code Crv. Proc. § 1198.1(a); Howard v. Societa di Unione e. Beneficenza Italiana, 62 Cal. App. 2d 842, 145 P.2d 694 (1944); Umion Tank \& Pipe Co. v. Mammoth Oil Co., 134 Cal. App. 229, 25 P.2d 262 (1933).

46 Cal. Code Crv. Proc. \$ 1198.1(a); Kane v. Hozz, 230 Cal. App. 2d 75, 40 Cal. Rptr. 701 (1964).

47 Cal. Code Crv. Proc. \$ 1198.1(a); Fontana Paving, Inc. v. Knecht, Garrison \& Tait Associates, 238 A.C.A. 840, 48 Cal. Rptr. 199 (1965).

48 Cal. Code Crv. Proc. § 1198.2. 
(b) The Priority System.-The priority rules ${ }^{49}$ may render the mechanics lien a valueless security device. The improver in such a situation should utilize the stop notice remedy ${ }^{50}$ The lender usually is protected because it is his security that has priority. The owner, of course, loses whatever interest he has in the property.

(c) Personal Liability.-An improver is not restricted to the mechanics lien remedy, but may maintain a personal action against the party who contracted for labor or materials, either in conjunction with or separately from an action to foreclose a mechanics lien. ${ }^{51}$ Previously obtaining a personal judgment and attempting to satisfy it by execution do not impair the improver's right to a mechanics lien, nor does foreclosing the lien affect the right to a personal judgment. ${ }^{52}$ An election of remedies is not required. ${ }^{53}$ It is apparent, therefore, that the "one form of action" rule, which requires a mortgagee first to proceed against the security before seeking a personal judgment, ${ }^{54}$ does not apply to the nonconsensual mechanics lien security device. ${ }^{55}$

49 Cad. Code Crv. Proc. \& 1188.1; see Hopkins, Selected Mechañics Lien Priority Problems, 16 Hastravgs L.J. 155 (1964); Comment, 51 CaLIF. L. Rev. 331, 341-45 (1963).

The priorities rules-and the related provisions dealing with "commencement" of work on an improvement-are important and moderately complicated, but adequately treated in other secondary sources. See generally Comment, 51 CarF. L. REv. 331, 341-45 (1963).

One interesting problem is suggested by the recent case of Parsons v. Bristol Dev. Co., 62 Cal. 2d 861, 402 P.2d 839, 44 Cal. Rptr. 767 (1965). The case held that an architect did not have a claim since a contractual condition precedent had not been performed. The case did not reach the question of whether the architect was entitled to the mechanics lien he had asserted. If it had been held that the architect had a lien under $\$ 1181$, then the next question would have had to be whether the lien had any priority. Since under the facts of the case the work of improvement never was commenced by beginning construction and since under § 1188.1 priority of the lien is from commencement of the improvement, it would seem that any lien the architect may have had would be subordinate to any other encumbrance that came along, since a date never was established from which the hen had priority. See Cat. Code Crv. Proc. § 1188.1.

"See part I, C infra this article.

51 Cas. Code Crv. Proc. § 1200; Bettigen Lumber Co. v. Kerrin, 99 Cal. App. 686, 279 Pac. 163 (1929). The two remedies are cumulative. Culbertson v. Cizek, 225 Cal. App. 2d 451, 468, 37 Cal. Rptr. 548, 557 (1964). The claimant is entitled to satisfy the indebtedness only once. Any money collected under either the personal judgment or foreclosure of the lien must be credited against both judgments. CaI. Cone Crv. Proc. § 1200; Culbertson v. Cizek, supra at 468, 37 Cal. Rptr. at 557.

52 Cal. Code Civ. Proc. \$ 1200; Norman v. Berney, 235 A.C.A. 515, 45 Cal. Rptr. 467 (1965); Culhertson v. Cizek, supra note 51; Bettigen Lumber Co. v. Kerrin, supra note 51.

53 Norman v. Berney, supra note 52 , at 521,45 Cal. Rptr. at 472 .

54 Car. Cone Civ. Proc. § 726.

65 In Culbertson v. Cizek, 225 Cal. App. 2d 451, 37 Cal. Rptr. 548 (1964), the trial court, in granting the unpaid secondary improvers a judgment of foreclosure against the owner's property as well as a personal judgment against the prime contractor and the surety, directed that the judgment be enforced by first proceeding against the owner's property. Only then was the deficiency, if any, to be collected from the prime contractor and the surety. The appellate court reversed this directive: Since lien claimants 
Although the statutes do not designate the persons incurring personal liability to the improver, ${ }^{56}$ it seems clear that personal liability is imposed in accordance with ordinary principles of contract law, based upon the personal promise to pay. ${ }^{57}$ Although a secondary improver may obtain a personal judgment against the person with whom lie contracted, he is not entitled to such a judgment against the owner since, by definition, lie has no contractual relationship with the owner. ${ }^{58}$ Statutory agency under section 1182 (c) does not place the owner in privity of contract with parties employed by statutory agents as far as personal liability is concerned. ${ }^{59}$ Ordinarily, therefore, the improver seeking a personal judgment must establish the existence of a contract, express or implied, entered into directly with the party being charged or with that party's actual (and not statutory) agent. ${ }^{60}$

have cumulative and simultaneous remedies-the personal action and the lien actionthe trial court lacked authority to make the owner's property primarily liable and place the prime contractor and the surety "in a considerably less exposed position of secondary liability." Id, at 469, 37 Cal. Rptr. at 557.

56 Cahifornia Code of Civil Procedure $\$ \S 1199.2$ and 1200 authorize the unpaid improver to obtain a personal judgment for the amount of the debt due bim, or a deficiency judgment for the balance due following foreclosure and sale of the property subject to the lien. With respect to the personal judgment, \$ 1199.2 refers to "the party personally liable" and $\$ 1200$ to "the person personally hable."

57 Golden Gate Bldg. Materials Co. v. Fireman, 205 Cal. 174, 270 Pac. 214 (1928); Pierce Eng'r Co. v. Chohon, 196 Cal. App. 2d 516, 16 Cal. Rptr. 601 (1961); see Shelley v. Casa de Ora, 133 Cal. App. 2d 720, 24 P.2d 900 (1933). The court in Pierce stated that "to justify a personal judgment against the owner ... the plaintiff [improver] must show the existence of a contract, express or imphed between the plaintiff and the owner." 19 Cal. App. 2d at 518, $16 \mathrm{Cal}$. Rptr. at 602 .

58 See Golden Gate Bldg. Materials Co. v. Fireman, supra note 57; Mott v. Wright, 43 Cal. App. 21, 184 Pac. 517 (1919); Los Angeles Pressed Brick Co. v. Higgins, 8 Cal. App. 514, 97 Pac. 414 (1908). In Golden Gate, the court stated: "A lien claimant who has furnished materials at the instance of a contractor is entitled to a personal or deficiency judgment against the contractor but not against the owner, unless the complaint shows the existence of a contract, express or implied, between said owner and the claimant." 205 Cal. at 177-78, 270 Pac. at 215.

50 The concept of statutory agency is discussed in part I, A, 1, a supra this article. A distinction must be drawn between "agents" of the owner and "statutory agents." Every person having charge of a part of the work of improvement is deemed to be a statutory agent of the owner, Cax. Code Crv. Proc. $\$ 1182(\mathrm{c})$, but only to the extent that an im. prover who enters into a contract with the statutory agent may establish a lien on the owner's land or improvement if not paid, CAL. Code Crv. Proc. $\S 1181$. The owner is not exposed to personal liability for contracts made by statutory agents or independent contractors. See Ridens v. Economy Home Builders, 104 Cal. App. 677, 286 Pac. 481 (1930); Mott v. Wright, 43 Cal. App. 21, 184 Pac. 517 (1919). In instances in which the owner has authorized other persons to enter into contracts in his behalf, the owner will be "personally liable" according to ordinary agency law and thus exposed to personal and deficiency judgments under the provisions of California Code of Civil Procedure $\$ \$ 1200$ and 1199.2. See Ingersoll v. Chaplin, 127 Cal. App. 290, 15 P.2d 790 (1932).

60 Golden Gate Bldg. Materials Co. v. Fireman, 205 Cal. 174, 270 Pac. 214 (1928); Pierce Eng'r Co. v. Chohon, 196 Cal. App. 2d 516, 16 Cal. Rptr. 601 (1961); Shelley v. 
(d) Deficiency Judgments.-Just as section 1200 allows a personal action against "the person personally liable," section 1199.2 authorizes the improver to foreclose a mechanics lien and secure a deficiency judgment against "the party personally liable." ${ }^{62}$ The statute further provides that actions to foreclose the lien and secure the deficiency judgment are to be treated "in like manner and with like effect as in [an] action for the foreclosure of mortgages"; ${ }^{63}$ this provision conceivably could raise problems under section $580 \mathrm{~b}$ of the Code of Civil Procedure, a section of the antideficiency legislation. ${ }^{64}$

Section $580 \mathrm{~b}$ deals with the security device given as a purchase inoney security. It could be argued that a mechanics lien fundamentally is a purchase money security device: An improver basically is a vendor of labor and materials imcorporated into the work of improvement; the mechanics lien secures payment of the purchase price of the labor and materials which become realty by attachment to the real property; ${ }^{65}$ and therefore the antideficiency protection of section $580 \mathrm{~b}$ is made applicable to the lien by the reference in section 1199.2 to foreclosing with like effect as mortgages. This, of course, would mean that no inprover contracting with an owner could obtain a deficiency judgment against lim. This result would be contrary to decided cases ${ }^{66}$ to the general purpose of section 1199.2, and to the specific provision of section 1200 that "Nothing contained in this chapter shall be construed to impair or affect the right of any person to whom any debt may be due for work done or materials furmished ... to maintain a personal action to recover said debt ...."

\section{B. Equitable Liens}

The equitable lien on construction funds is a judicially created remedy granted to improvers in "special circumstances warranting the imposi-

Casa de Ora, 133 Cal. App. 720, 24 P.2d 900 (1933); Ingersoll v. Chaplin, 127 Cal. App. 290, 15 P.2d 790 (1932); Ridens v. Economy Home Builders, 104 Cal. App. 677, 286 Pac. 481 (1930). In establishing the existence of an implied contract, an improver enjoys the assistance of a rebuttable presumption that "where services are rendered by one party from which another derives benefit, ... the person enjoying the benefit is bound to pay what the services are reasonably worth." Pierce Eng'r Co., supra at 518, 16 Cal. Rptr. at 602 .

61 Car. Code Civ. Proc. § 1200.

62 Cal. Code Crv. Proc. § 1199.2 .

63 Ibid.

64 The antideficiency provisions in $\S 580 d$ of the Code of Civil Procedure deal with the situation where the security device is foreclosed pursuant to a power of sale. This clearly would not be applicable to mechanics liens which must be foreclosed judicially.

65 See Cal. Crv. Code $\$ 658$.

06 See, e.g., Pierce Eng'r Co. v. Chohon, 196 Cal. App. 2d 516, 16 Cal. Rptr. 601 (1961). Apparently the point was not expressly considered in Pierce Eng'r. 
tion" of the ben. ${ }^{67}$ The equitable lien is wholly independent of the statutory mechanics hen and stop notice remedies, but like the stop notice the claim is against undisbursed construction funds rather than against the improvement. An improver is not entitled to an equitable lien merely because he is entitled to a mechanics lien or stop notice. ${ }^{68}$ Unfortunately, however, it is not altogether clear what "special circumstances" need be shown to entitle an improver to an equitable lien.

There seem to be two general requirements: first, that the unpaid improver was induced to rely on the availability of a construction loan fund for payment rather than on personal credit; and second, that it would be unjust to allow the lender or owner-borrower to withliold the money from the unpaid improver. Decisions based primarily on a finding that the loan contract created an express trust fund for the benefit of improvers $^{69}$ or was executed for the benefit of third party improvers, ${ }^{70}$ sensibly should be excluded from the equitable lien doctrine, for these decisions did not turn on factors extrinsic to the loan contract.

\section{Inducement and Reliance}

Inducement to rely and reliance on the construction fund are said to be prerequisites to the equitable hien remedy, but it appears that these requirements are recited more than observed. Smith v. Anglo-California Trust Co. ${ }^{71}$ and Pacific Ready Cut Homes v. Title Ins. \& Trust Co. ${ }^{72}$ were the first cases to state the need for inducement and reliance but indicated that these elements could be inferred from the circumstances without great difficulty. Each case suggests that an improver's knowledge that a construction loan has been negotiated may be sufficient circumstantial evidence of justifiable reliance, since the lender should have known that an improver would be induced to supply goods or services

67 Smith v. Anglo-California Trust Co., 205 Cal. 496, 502, 271 Pac. 898, 901 (1928).

68 A-1 Door \& Materials Co. v. Fresno Guar. Sav. \& Loan Ass'n, 61 Cal. 2d 728, 394 P.2d 829, 40 Cal. Rptr. 85 (1964). The court in Miller v. Mountain View Sav. \& Loan Ass'n, 238 A.C.A. 759, 780, 48 Cal. Rptr. 278, 292 (1965), hearing denied, 64 A.C. Minutes 8 (Feb. 2, 1966), without citing authority, observed: "It is generally indicated that the recording of a claim of lien is condition precedent to the assertion of an equitable lien even though such fact alone ... [is] not enough to give rise to such a lien." The court may have been thinking of language from Hayward Lumber \& Inv. Co. v. Coast Fed. Sav. \& Loan Ass'n, 47 Cal. App. 2d 211, 213, 117 P.2d 682, 683 (1941), but Hayward clearly does not support the proposition.

${ }^{69}$ E.g., Whiting-Mead Co. v. West Coast Bond \& Mortgage Co., 66 Cal. App. 2d 460, 152 P.2d 629 (1944).

70 E.g., Ralph C. Sutro Co. v. Paramont Plastering, Inc., 216 Cal. App. 2d 433, 31

Cal. Rptr. 174 (1963).

71205 Cal. 496, 271 Pac. 898 (1928).

72216 Cal. 447, 14 P.2d 510 (1932). 
in reliance on the reputable financial backing evidenced by the loan agreement.

In A-1 Door \& Materials Co. v. Fresno Guar. Sav. \& Loan Ass'n, ${ }^{73}$ a somewliat stricter rule was suggested: "An equitable lien may be imposed on a construction-loan fund only if it is establislied that the borrower or lender induced the supplier of labor or materials to rely on the fund for payment." ${ }^{74} A-1$ Door demed an equitable hen on facts which apparently would have been sufficient to infer inducement and reliance under Smith, implying that direct inducement and express reliance miglit be required. Subsequently, however, the first district court of appeal in Miller v. Mountain View Sav. \& Loan Ass' $n^{75}$ found sufficient evidence to support the requisite inducement-reliance element from something less than direct inducement and express reliance. The only evidence supporting inducement and reliance was that the improver liad received some payments from a joint control agent of the lender. "In setting up this system of making payments [the lender] . . . can be charged with inducing reliance on the payments it would make, and [the improver] . . . can be said to have relied on the payments to be made . . . by a financial institution, even though he did not then know its identity." decisions appear to reach conflicting results suggesting that inducement and reliance liave not in fact been the criteria for the equitable lien.

\section{Unjust Enrichment}

Both Smith and Pacific Ready Cut emphasized the unfairness of leaving improvers unpaid while there was an unexpended balance in the construction loan fund. Furthermore, in Pacific Ready Cut, ${ }^{77}$ denying an equitable lien would have resulted in a profit to the owner to the extent that the unexpended balance of the loan would have been used to reduce the loan. In each case, the lien was allowed. In $A-1$ Door, however, the project was not completed, and the lender may liave had to use the remaining money to finisl construction; there was no slowing of unjust enrichment. The lien was denied. In Miller, where the lien was permitted even though the project was incomplete, the lender had realized a substantial profit on a sale under the deed of trust. If the lien had been denied, the lender would have been enriched at the expense of improvers

7361 Cal. 2d 728, 394 P.2d 829, 40 Cal. Rptr. 85 (1964).

74 A-1 Door \& Materials Co. v. Fresno Guar. Sav. \& Loan Ass'n, 61 Cal. 2d 728, 732, 394 P.2d 829, 832, 40 Cal. Rptr. 85, 88 (1964).

75 238 A.C.A. 759, 48 Cal. Rptr. 278 (1965), hearing denied, 64 A.C. Minutes 8 (Feb. 2, 1966).

78 Id. at 779, 48 Cal. Rptr. at 291.

77216 Cal. 447, 14 P.2d 510 (1932). 
whose goods and services had increased the value of the structure and had made the profit possible.

The existence of unjust enrichment appears to be the factor upon which the equitable hen decisions turn. The need for inducement and reliance, though often articulated, is uncertain. It is sound to base the remedy on unjust enrichment: An improver should not be required to forfeit the value of his labor or materials to the extent the owner or lender would realize a windfall. The owner and the lender would be adequately protected by the unjust enrichment requirement even without the additional elements of inducement and reliance, since they would be required to disgorge only unexpected profits.

It has been suggested that any extension of the equitable lien remedy would make it "generally co-extensive in purpose and effect" with the statutory stop notice provisions, but without the attendant protective features, such as notice and bond. ${ }^{78}$ There is merit to this view, but the statutory provisions will not be supplanted as long as unjust enrichment is required.

\section{Stop Notices}

The statutory stop notice (or notice to withhold) permits an unpaid secondary improver to enter a claim against uudisbursed construction funds. ${ }^{79}$ The stop notice, particularly in view of recent case developments, is a most effective weapon for secondary improvers. It avoids the priorities problems of mechanics liens by giving secondary improvers a claim on undisbursed construction funds. Further, it avoids problems attendant upon the uncertainties of the equitable hien remedy.

The stop notice is a remedy distinct from and unrelated to the mechanics lien except for certain common procedural requirements. On a private construction job, an improver may perfect a mechanics lien against the improvenient as well as a stop notice against the undisbursed funds. ${ }^{80}$ On public works of improvement, the stop notice is the only device available to the improver since liens against state-owned realty are disallowed as contrary to public policy. ${ }^{81}$

78 Comment, 5 Santa Clara Law. 69, 74 (1964).

79 Cad. Code Crv. Proc. $\S 1190.1(\mathrm{a})$, (c), (h). The notice is required to contain certain specific information. It must give a general description of the kind of labor or materials furnished or to be furnished, to whom furnished, and the approximate value. CAI. CODE CNv. Proc. \& 1190.1(a). The notice must he verified and delivered personally, Car. Code Crv. Proc. \& 1190.1(b), or by registered mail, CAL. Code Crv. Proc. \$ 1190.1(1), to the owner or architect, CAI. CoDE Crv. Proc. $\S 1190.1$ (b). If a construction loan has been made the notice must be delivered to the manager of the banking branch at which the funds are being disbursed. CAI. CODE Crv. Proc. \& $1190.1(\mathrm{k})$.

80 A-1 Door \& Materials Co. v. Fresno Guar. Sav. \& Loan Ass'n, 61 Cal. 2d 728, 732, 394 P.2d 829, 832, 40 Cal. Rptr. 85, 88 (1964) ("The [mechamics lien and stop notice] remedies are independent and cumulative.").

81 See Thiesen v. County of Los Angeles, 54 Cal. 2d 170, 352 P.2d 529, 5 Cal. Rptr. 
Except for the primary contractor, any party who is entitled to file a mechanics lien ${ }^{82}$ also may file a stop notice with any person loolding construction funds, whether that person is the owner, ${ }^{83}$ third-party lender, ${ }^{84}$ or escrow agent. ${ }^{85}$ The notice must be given after the claimant has agreed to furnish labor or materials but before the expiration of the period within which mechanics liens would have to be recorded. ${ }^{86}$ A suit to enforce the stop notice must be maugurated within a period of ninety days after the last day on which a mechanics lien may be recorded. ${ }^{87}$ An enforceable stop notice creates a duty on the part of one holding construction funds to withhold an amount sufficient to cover the claim. ${ }^{88}$ Failure to respect an effective stop notice renders the fundholder personally hable to the claimant. ${ }^{89}$

\section{Procedural Steps}

As far as private construction projects are concerned, the procedures for perfecting stop notices differ depending on the type of construction money that is involved: (a) construction financed entirely with personal funds of the owner; or (b) construction financed with a construction loan.

(a) Owner Financing.-When the owner is financing construction with his own fumds, unpaid improvers may give to the owner "a notice that they have performed labor or furnished materials ... or that they have agreed to do so," ${ }^{\prime 90}$ and the owner then must withhold from the

161 (1960); Clark v. Beyrle, 160 Cal. 306, 116 Pac. 739 (1911); Bates v. Santa Barbara County, 90 Cal. 543, 27 Pac. 438 (1891); United States Fid. \& Guar. Co. v. Oak Grove Union School Dist., 205 Cal. App. 2d 226, 22 Cal. Rptr. 907 (1962); Powers Regulator Co. v. Seaboard Sur. Co., 204 Cal. App. 2d 338, 22 Cal. Rptr. 373 (1962).

82 CaL. Code Crv. Proc. $\$ 1190.1$ (a). Sections 1181 and 1184.1 specify the persons entitled to file a mechanics lien. Statutory agency is important for determining the persons entitled to assert mechanics liens and therefore entitled to file stop notices. See part I, A, 1 , a supra this article.

83 CaL. Code Civ. Proc. $\$ 1190.1$ (a).

84 Cal. Code Crv. Proc. $\$ 1190.1(\mathrm{l})$.

85 Ibid.

88 CaL. Code Crv. Proc. $\S \S 1190.1(a)$, (h). See part I, A, 1, b supra, of this article. A stop notice may be filed "prior to the expiration of the period within which claims of [mechanics] lien must be filed for record." CaL. Code Crv. Proc. \$ 1190.1(a), (II). Apparently the fifteen-day notice requirement of $\$ 1193$ does not apply to stop notices.

The notice must include certain information specified by $\S 1190.1(\mathrm{a})$. See note 70 supra. A claimant loses the right to a stop notice if he refuses to give the notice upon the written demand of the owner. Cal. Code Crv. Proc. $\S 1190.1$ (a).

87 Cat. Code Crv. Proc. \$ 1197.1(a). The trial court has discretion to dismiss the action if it is not brought to trial within two years. Cal. Cone Crv. Proc. $\$$ 1197.1(a).

88 Cad. Code Civ. Proc. $\$ 1190.1$ (c), (h).

89 H. O. Bragg Roofing, Inc. v. First Fed. Sav. \& Loan Ass'n, 226 Cal. App. 2d 24, 37 Cal. Rptr. 775 (1964).

90 CAL. Code Crv. Proc. $\$ 1190.1$ (a). It should be noted that $\$ 1190.1$ (a) authorizes an improver to file a notice that he has agreed to furnish labor or materials. In the case 
funds due or that may become due to the prime contractor an amount sufficient to satisfy the claims. ${ }^{.1}$ There is no statutory requirement that the stop notice be accompanied by an indemnity bond in order to place a mandatory duty on the owner to withhold. The owner, however, need not respect the stop notice if the prime contractor has furnished a labor and material payment bond under section $1185.1 .^{92}$

(b) Third-party Financing.- Where a construction loan has been negotiated with a third-party lender, an unpaid secondary improver may file a stop notice with the person holding the funds. ${ }^{03}$ The person holding the proceeds of a construction loan may set aside sufficient money to satisfy the claim but has no obligation to do so unless an indemnity bond also is furnished with the notice. ${ }^{04}$

The fact that an unbonded stop notice has different effects, depending on whether it is given to an owner or a lender, theoretically may pose difficulties for the owner who holds borrowed funds for disbursement. Subsections (a) and (c) of section $1190.1^{08}$ create a duty to withhold without regard to whether an indemnity bond is filed when a stop notice is given "to the owner." Subsection (h), ${ }^{97}$ however, provides that honoring an unbonded stop notice is permissive "in any instance in which the

of a mechanics ben, however, $\$ 1193.1$ (a) provides that an improver other than an original contractor may file a claim of lien only "after he las ceased to perform labor or furnish material ...." An improver, therefore, may file a stop notice hefore he is allowed to file a mechanics lien.

01 Cat. Code Crv. Proc. § 1190.1(c). There is some indication that the owner's duty to withhold is not limited to the amount due from the owner to the primary contractor. Sce part I, C, 2, b infra this article.

92 CAL. Code CTV. Proc. \$ 1190.1(c). The "labor and material payment bond" guarantees that improvers will be paid money due them for labor and materials furnished to the project covered by the bond. See CAI. CODE Crv. Proc. $\S 1185.1$. The bond and the original contract must be recorded pursuant to $\$ 1185.1$ before the owner is free to ignore stop notices. CAL. CODE CIV. PrOC. \$ 1190.1(c). Failure to record the bond does not affect the liability of the surety unless the bond itself requires filing as a prerequisite to validity. Culbertson v. Cizek, 225 Cal. App. 2d 451, 37 Cal. Rptr. 548 (1964).

${ }^{03}$ CAI. Code CIr. PROC. $\S 1190.1$ (h). The notice must contain the information specified in $\$ 1190.1$ (a).

84 CAI. Code Crv. Proc. $\$ 1190.1$ (1). The indemnity bond is a guarantee by the surety that the claimant will pay all costs and damages in connection with the suit if the asserted claim is invalid. The bond must be in the amount of one and one-quarter times the amount of the improver's claim, and must be issued by "good and sufficient sureties." Ibid. The fundholder can object to the sufficiency of the sureties within twenty days after service of the notice. CaI. Code Cry. Proc. $\$ 1190.1(\mathrm{~m})$.

95 As a practical matter, the owner will end up in this limbo infrequently since institutional lenders generally require the borrower to assign the proceeds of a construction loan to the lender or to a joint control agency to maintain some control over disbursement of the funds.

80 Cal. Code Crv. Proc. \$ 1190.1(a), (c).

07 Car. Code Crv. Proc. § $1190.1(\mathrm{~h})$. 
funds with which the cost of the work of improvements are . . . to be defrayed from the proceeds of a building loan." The owner disbursing borrowed money seems to come within both provisions. Subsection (h) probably would govern, since it concerns the character of the money being used for construction, not the identity of the person holding the money: It applies to the proceeds of a building loan whether held by "the mortgagee, beneficiary under a deed of trust, . . . escrow holder, or other party ...." ."98

\section{Problems of the Owner and the Institutional Lender}

Construction money lenders now are obliged by self-interest to participate actively in the supervision of a construction project. This enforced participation results from recent court decisions extending the effectiveness of the stop notice remedy. Lenders now basically have but two choices: to require bonds or to gamble on underwriting the project to completion. ${ }^{99}$

There is one fundamental difference between stop notices and mechanics liens that must be understood: Personal liability arises if one fails to respond to a stop notice to which he should have responded; the mechanics lien, however, merely is a lien on the improvement and, to a himited extent, on the land upon which the improvement is situated. There is no personal hability associated with a mechanics lien unless the lien claimant is able to establish the existence of a contract, in which case liability stems from the contract and not from the mechanics hen.

In A-1 Door \& Materials Co. v. Fresno Guar. Sav. \& Loan Ass'n, ${ }^{100}$ the California Supreme Court held that a lender who receives a bonded stop notice must withhold sufficient money from the balance of the construction loan to satisfy the claim, without regard to whether any money is due under the terms of the loan contract and without regard to whether construction is coinpleted. In $A-1$ Door, the owner of a proposed construction project borrowed a specified amount of money from an institutional lender, securing the loan with a first deed of trust. The loan then

88 The provisions of $\S 1190.1(a)$ and (c), under this interpretation, would apply only when the owner held personal funds for construction. Since the owner is personally liable for ignoring an effective stop notice, Rossman Mill \& Lumber Co. v. Fullerton Sav. \& Loan Ass'n, 221 Cal. App. 2d 705, 34 Cal. Rptr. 644 (1963), and since the statutory conflict is unsettled, the owner probably should respect an unbonded stop notice even though the funds he holds were provided by a lender.

Under $\$ 1190.1(h)$ the one holding funds inay honor an unbonded stop notice but is not required to. The prime contractor then could obtain the withheld funds by posting an appropriate bond. CAT. Code CTv. Proc. \& 1190.1(j).

90 Cf. Comment, 53 CAIIF. L. REv. 1062 (1965).

10061 Cal. 2d 728, 394 P.2d 829, 40 Cal. Rptr. 85 (1964). 
was assigned back to the lender to be disbursed in five installments, with the last installment due only after the project had been completed. ${ }^{101}$ Construction ceased after the fourth progress payment, and the project was never completed. Consequently, no inoney was due under the loan contract, and there was nothing to "garnish" in the sense of attaching an existing debt. Bonded stop notices were filed with the lender by several unpaid improvers. The lender was required to pay the claims even though no money was due under the loan contract.

The result was predicated upon two grounds. First, a bonded stop notice places a mandatory duty upon the lender to withhold sufficient money out of the construction loan "fund." The extent of the fund from which the lender must withhold is defined in section 1190.1(h) to include all money "furnished or to be furnished by ... the lender ... or arising out of a construction or building loan." The fund is not limited to the money due under the loan contract. A private agreement between the lender and the borrower, whether in the form of progress payments or otherwise, may not restrict the amount of the fund available to bonded stop notice claimants. Second, the lender in this case had transferred the fund to the owner-borrower who subsequently assigned the entire amount back to the lender for disbursement in progress payments. Section $1190.1(\mathrm{~h})$ invalidates such an assignment as far as the rights of bonded stop notice claimants are concerned. ${ }^{102}$

It appears that the case could have been decided solely on the basis that the assignment was ineffective as to bonded stop notice claimants. However, since the court took care to define the extent of the "fund" available to stop notice claimants and to state that no agreement between the borrower and the lender can effect the size of the fund, it is necessary to conjecture what the court was trying to communicate.

(a) Mandatory Advances. - It is doubtful that the rationale of A-1 Door is himited to those situations in which the undisbursed funds are the balance of an original lump-sum loan. Construction financing under an arrangement for mandatory advances ${ }^{103}$ probably will receive the same treatment. Although the question of advances was not expressly decided in $A-1$ Door, the court was explicit in stating that bonded stop

101 The assignment permitted the lender to collect interest on money with which it had not parted.

102 CaI. CODE Crv. Proc. \$ 1190.1(h). The last sentence reads: "No assignment by the owner or contractor of construction loan funds, whether made before a verified claim is filed, or after such claim is filed shall be held to take priority over claims filed under this subsection (h) and such assignment shall have no binding force insofar as the rights of claimants who file claims hereunder are concerned."

103 "Mandatory advances" are commitments to make payments if specified conditions are met. For purposes of this article, it is assumed that the conditions for payment relate primarily to reaching a specified stage of completion of the improvement. 
notice claimants can reach any money which is "to be furnished" by the lender to pay construction costs, or which "arises out of a construction loan," without regard to whether the money is due under the terms of the loan contract. ${ }^{104}$ The court said, "The requirement that the fundholder withhold claimed funds applies not only when his contract calls for payment but even when it does not." ${ }^{2105}$ Clearly this could include future mandatory advances as well as future progress payments. Furthermore, there is no reason why mandatory advances should receive different treatment. The intention of the lender is the same for mandatory advances as for progress payments under a lump-sum loan: In each case construction must progress to a specified stage of completion before the lender is under a duty to release additional money to finance the project. The lender's deed of trust has the same priority whether the loan is for mandatory advances or for a lump sum with progress payments. ${ }^{106}$

(b) Personal Liability.-A dictum in $A-1$ Door indicates that the owner's liability to stop notice claimants is the same as that of the lender. ${ }^{107}$ This result would ignore explicit differences in the statutory language defining the duties of the owner ${ }^{108}$ and of a lender, ${ }^{109}$ and would ignore the presumed difference in busmess acumen between the institutional lender and the ordinary liome owner.

The owner's duty to respond to a stop notice is established in subsection (c), ${ }^{110}$ while the lender's duty comes from subsection (h).$^{111}$ The owner must respect a stop notice even though it is not accompanied by an indemnity bond, but is required to withhold only money "due or

104 "The fundholder must therefore withhold from funds furmished to pay construction costs or arising out of a construction loan sufficient money to answer bonded stopnotice claims regardless of the terms of its contract with the owner. . . Subsection (h) requires that funds earmarked for construction purposes be used to pay supphers of labor and materials who file claims under the subsection and therefore supersedes the private arrangements of borrower and lender." 61 Cal. 2d at 734, 394 P.2d at 833-34, 40 Cal. Rptr. at 89-90.

105 A-1 Door, supra note 104, at 734, 394 P.2d at 833, 40 Cal. Rptr. at 89.

100 Under each of these arrangements the priority of the deed of trust is from the time it is first recorded, regardless of the time the money is actually disbursed. Rheem Mfg. Co. v. United States, 57 Cal. 2d 621, 371 P.2d 578, 21 Cal. Rptr. 802 (1962); Fickling v. Jackman, 203 Cal. 657, 265 Pac. 810 (1928). The security for the mandatory advance, then, will be senior to any mechamics hen as long as the deed of trust was recorded before work on the improvenient was commenced.

$10761 \mathrm{Cal}$. 2d at 733, 394 P.2d at $833,40 \mathrm{Cal}$. Rptr. at 89. The court was discussing whether a stop notice clain under $\S 1190.1(\mathrm{~h})$ is the same as an equitable garnishment, and therefore dependent on the existence of a debt owed by the garnishee to the debtor. In rejecting this proposition the court digressed by discussing $\S 1190.1$ (c), which deals with the liability of the owner.

108 CaI. Code Civ. Proc. § 1190.1(c).

100 Cal. Code Civ. Proc. \$ 1190.1(h).

110 CaL. Code Civ. Proc. \$ 1190.1(c).

111 CaI. Code Civ. Proc. \& 1190.1(h). 
that may become due" to the contractor. ${ }^{112}$ Subsection (h), however, permits the assertion of a stop notice against any person holding funds "to pay construction costs or arising out of a construction or building loan." 113 Subsection (h) does not limit the funds available to the claimant to those "due or to become due to the borrower." Subsection (c), it should be noted, does not speak in terms of a hypothetical "fund" from which money must be withheld. To hold that the owner using his own money for construction must honor unbonded stop notices without respect to whether any money is due the contractor or ever may become due ${ }^{114}$ does not amount to equating liability of the owner and lender. Instead this would delete the language from subsection (c) limiting the owner's liability to the amount "due or to become due," without adding the language from subsection (h) limiting liability to a hypothetical fund and requiring that the stop notice be accompanied by a bond.

It is reasonably clear that the owner's liability under subsection (c) includes the reasonable value of work and materials furnished but for which payment has not been made. Even though the prime contractor has abandoned the contract and no money is due or will become due, the owner is not permitted to receive value without paying for it. "[I]n case of abandonment the difference between the sum paid to the contractor and the value of work and material which the contractor has furnished and for which the owner has not paid shall be treated as the fund available to the hen claimants."115 This is somewhat different from the way the same

112 Secondary improvers (all persons mentioned in $\$ \$ 1181$ and 1184.1 except the contractor) may give a stop notice to the owner prior to the expiration of the time within which mechanics liens must be recorded under $\S 1193.1$. Car. Code Crv. Proc. $\S 1190.1(a)$. "Upon such notice being given it shall be the duty of the person to whom sucl notice is given to ... withhold from his contractor or from any person acting under his authority and to whom said labor or materials ... have been furnished, ... sufficient moncy ... due or that may become due to such contractor to answer such claim . . . " CAL. CoDE Crv. Proc. \& 1190.1(c). (Emphasis added.)

113 Section 1190.1(h) of the Code of Civil Procedure permits secondary improvers (any persons mentioned in $\S \S 1181$ and 1184.1 except the contractor) to give a notice similar to the one provided for in $\$ 1190.1$ (a) prior to the expiration of the period within which mechanics liens must be recorded under $\S 1193.1$ : "in any instance in which the funds with which the cost of the work of improvements are [sic], wholly or in part, to be defrayed from the proceeds of a building loan ...." The notice may be given to the mortgagee, beneficiary under a deed of trust, or assignee or successor in interest of cither, as well as to any escrow holder "or other party holding any funds furnished or to be furnished by the owner or lender or any other person as a fund from which to pay construction costs or arising out of a construction or building loan ...." The person given the notice may withhold funds but is under no obligation to do so unless an indemnity bond is furnished by the claimant.

114 Probably none ever would be due if the contractor clearly laad breached his contract and had indicated unequivocably that he would not perform further.

115 Stettin v. Wilson, 175 Cal. 423, 426-27, 166 Pac. 6, 7 (1917). See also Ilyin, Stop Noticel-Construction Loan Officer's Nightmare, 16 HastnsGs L.J. 187, 192 (1964). 
rule was characterized by the court in $A-1$ Door, however: "[T]he terms of the owner's contract with his contractor, which would have barred any recovery by the contractor because he had abandoned his contract, did not preclude recovery from the owner by stop-notice claimants. That there was no money due under the contract was held not to be determinative of the issue."116 The dictum in $A-1$ Door, if it correctly states the rule, means that the owner is exposed to liability previously unsuspected. As far as the owner is concerned, the stop notice would be a vicious weapon. Since the liability of the owner under subsection (c) is not limited to the amount of the "fund" as is the hability of the lender under subsection (h), presumably the owner's liability would not even be limited by the prime contract price. Apparently the owner would be placed in the same position for stop notices that his property now is in for mechanics liens. The only limitation on his liability would be either the reasonable value of the goods or services provided by the secondary improver, or the amount of the secondary improver's contract with the prime contractor. The critical difference between stop notices and mechanics hens, though, is that the owner is bound personally to respond to stop notices while only the improvement is available for mechanics liens. The A-1 Door dictum would make the owner personally hable for the contracts of lis statutory agents.

(c) Compulsory Bonding.-There remains for consideration the greatest impact of the $A-1$ Door case. No longer can the institutional lender view construction activity passively, for improvers by asserting stop notices can reach the entire amount the lender has agreed to loan. ${ }^{117}$ This well may mean that a lender will disburse the entire contract price without having a completed improvement as security for the loan. The extent to which the improvement is completed probably will depend on how badly the prime contractor bungled the job or on how much of the money was diverted from improvers who should have been paid. Institutional lenders can solve this problem in a number of ways: by secondguessing the prime contractor and recomputing the bid, by maintaining strict control over disbursements and in effect going into the joint control business, or by requiring that the prime contractor be bonded.

Some institutional lenders have chosen to accommodate $A-1$ Door by maintaining strict control over disbursements, discarding the progress payment system and substituting the more complex voucher system. ${ }^{118}$

11061 Cal. 2d at 733, 394 P.2d at 833, 40 Cal. Rptr. at 89.

117 Cf. Comment, 53 CaIr. L. Rev. 1062 (1965).

118 There is a general trend within savings and loan associations to employ vouchers in making disbursements. Interviews with Jon A. Nieman, loan officer of Lytton Sav. \& Loan Ass'n, Oakland Branch (100\% of Lytton's construction loans are on the voucher system), William E. Scarlett, ass't vice-president of the construction loan dept. of First 
Under the voucher system, the institutional lender makes payment directly to each improver upon presentation of a proper voucher. The use of vouchers may prevent a substantial diversion of construction funds and insure that the money is distributed properly, but in practice the system is not without fault. The possibilities of "padded" vouchers, vouchers improperly drawn to pay debts in connection with other projects, and similar devices leave open the opportunity of diverting funds.

Because of provisions in the Financial Code regulating institutional lenders, commercial banks and savings and loan associations are not supposed to advance funds in excess of a stated percentage of the value of the improvement completed prior to the advance. ${ }^{119}$ The institutional lender, however, may be required to respond to stop notices in amounts that exceed the disbursements allowed by the Financial Code. It has been held that when this happens the institutional lender is to honor the stop notice and bear the responsibility for laving violated the Financial Code. ${ }^{120}$ No matter how closely the institutional lender oversees a construction project, it has no assurance that it will not err and have to make advances in violation of the provisions of the Financial Code. Since a stop notice may be disregarded if the prime contractor is bonded, ${ }^{121}$ however, the institutional lender that requires a labor and material payment bond knows with substantial certainty that no unlawful advances will be required. Though the judiciary has pointed this out, ${ }^{122}$ institutional lenders do not appear to be histening. ${ }^{123}$

Unless lending institutions are willing to incur the risk of underwriting construction projects to completion, they will lend money only on

Sav. \& Loan Ass'n, Oakland Branch ( $99 \%$ of First Savings' construction loans are on the voucher system), Ken Kirk, loan officer of American Sav. \& Loan Ass'n, Oakland Branch (60\% of American Savings' construction loans are on the voucher system), Feb. 14, 1966. 119 CAI. FIN. CODE $\$ \S 1227$ (commercial banks), 7156 (savings and loan associations); Ilyin, supra note 115 , at 188 .

120 Rossman Mill \& Lumber Co. v. Fullerton Sav. \& Loan Ass'n, 221 Cal. App. 2d 705, 34 Cal. Rptr. 644 (1963).

121 Caz. Code Crv. Proc. § 1190.1(j).

122 "Furthermore a lender such as defendant can make loan funds immune from claims under section 1190.1, subsection ( $h$ ) by furnishing a inaterials and labor bond complying with the requirements of section 1185.1 of the Code of Civil Procedure. (Code Civ. Proc., \$ 1190.1, subsec. (j).)" A-1 Door \& Materials Co. v. Fresno Guar. Sav. \& Loan Ass'n, 61 Cal. 2d 728, 735, 394 P.2d 829, 834, 40 Cal. Rptr. 85, 90 (1964). "Financial Code section 7156 is designed to protect depositors against injudicious loan practices by savings institutions. The ratio formula was never intended to be a means of evading the responsibilities and obligations of the mechanic's lien laws of the State of California. It is particularly significant that a savings and loan lender can comply with both laws if it makes a conscious effort to do so." Rossman Mill \& Lumber Co. v. Fullerton Sav. \& Loan Ass'n, 221 Cal. App. 2d 705, 711, 34 Cal. Rptr. 644, 648 (1963).

123 See Ilyin, supra note 115 (written by general counsel for Guarantee Savings \& Loan Association of Yolo, Standard Savings \& Loan Association). 
bonded projects. This simple alternative of "no bond-no loan" would be unsatisfactory for the institutional lender which desires to loan money on a project for which the prime contractor cannot obtain a bond. In this situation, a combination of bonding and joint control may be possible. To the extent that work has been subcontracted to bondable subcontractors, the institutional lender could protect itself by requiring a bond of each subcontractor and treating each as a prime contractor. For work done by the unbonded prime contractor, the lender would have no choice but to carefully regulate disbursements, either by using a joint control agent or by using a voucher system. But disbursements under either control system would be at the lender's peril.

Both the improver and the owner benefit from the lender's increased participation in the construction project. It is in the lender's interest to see that improvers are paid, for unpaid improvers have a stop notice claim which, in effect, depletes the value of the lender's security. The owner who borrows will be an incidental beneficiary of the lender's efforts; the lender, in protecting his security, will be assisting the owner in obtaining his improvement for the contract price.

II

PROTECTION

Despite the difficulties that may be encountered under the mechanics lien and stop notice statutes, appropriate safeguards are available by which the relevant persons may protect themselves. For convenience, the different safeguards are grouped into three general categories: waivers, joint control, and bonds.

\section{A. Waivers}

The right to a mechanics lien may be waived, ${ }^{124}$ but only by authority of the particular improver who has the right by law to assert the lien. ${ }^{125}$

124 Giant Powder Co. v. Fidelity \& Deposit Co., 214 Cal. 639, 7 P.2d 1023 (1932). However, a waiver will extend only to lien rights existing at the time it is executed if ambiguous as to future lien rights. Consumers Holding Co. v. County of Los Angeles, 204 Cal. App. 2d 234, 22 Cal. Rptr. 106 (1962). See also CAL. Crv. Code $\$ 1542$ (general release does not extend to certain claims).

${ }^{125}$ CAx. Code CIv. Proc. § 1187.1. The most obvious example of waiver is failure by the improver to perfect or enforce the lien. The difficult procedural requirements with which improvers must comply in order to obtain an enforceable lien might be interpreted as a legislative intent to encourage waivers.

The owner may require improvers to provide him with the information contained in a stop notice. If an improver refuses to give the information after written demand by the owner, then the improver may not assert either a mechanics lien or a-stop notice. CAI. Code Crv. Proc. \& 1190.1(a). Thus, the owner may ascertain his potential liability, but only to the extent that lie knows the identity of improvers. 
Waiver turns on intent, which is a question of fact. ${ }^{128}$ Intention is clear when the waiver is in the form of an express written declaration, ${ }^{127}$ but the waiver need be neither written nor express. ${ }^{128}$ Intention to waive may be impled but, because of the constitutional and statutory source of the lien, only on clear evidence. ${ }^{129}$ An improver's acceptance of a promissory note or other security as payment for the labor and materials furnished may be held to be an implied waiver on the theory that the basic indebtedness was extinguished by substitution of the new security, leaving no debt upon which a lien could be predicated. ${ }^{130}$ But mere acceptance of a promissory note without more may not constitute an implied waiver; the note may have been taken only as evidence of the debt and not as payment or as a substitute for the original obligation. ${ }^{131}$

- Since actual payment of the debt due the improver would destroy the right to a lien, the improver will be denied a lien to the extent that money has been made available to him and he would have been paid but for his awn impropriety. ${ }^{132}$ In such a case, the improver is estopped from claiming nonpayment. ${ }^{133}$ An improver's receipt of a check payable both to him and to the prime contractor, with knowledge that the owner or lender is the source of the funds, places upon the improver a duty to apply the money on the maker's account notwithstanding the co-payee's consent to application elsewhere. ${ }^{134}$ The improver:will be denied a lien to the extent that the money is not treated in accordance with the maker's intent. ${ }^{135}$

\footnotetext{
126 Petaluma Bidg. Materials v. Foremost Properties, 180 Cal. App. 2d 83, 4 Cal. Rptr. 268 (1960); cf. Giant Powder Co. v. Fidelity \& Deposit Co., 214 Cal. 639, 7 P.2d 1023 (1932); Consumers Holding Co. v. County of Los Angeles, 204 Cal. App. 2d 234, 22 Cal. Rptr. 106 (1962).

127 Giant Powder Co. v. Fidelity \& Deposit Co., supra note 126. An express written waiver of lien rights, however, does not bar an unpaid improver from seeking payment by proceeding against the surety under the contractor's labor and materials payment bond. Fraters Glass \& Paint Co. v. Southwestern Constr. Co., 200 Cal. 688, 254 Pac. 1099 (1927); Bonded Prods. Co. v. Gallyon Constr. Co., 228 Cal. App. 2d 186, 39 Cal. Rptr. 347 (1964); Ferry v. Ohio Farmers Ins. Co., 211 Cal. App. 2d 651, 27 Cal. Rptr. 471 (1963).

${ }^{128}$ Wood Lumber Co. v. Higgins, 54 Cal. 2d 91, 351 P.2d 795, 4 Cal. Rptr. 523 (1960). 129 Martin v. Becker, 169 Cal. 301,146 Pac. 665 (1915); Bank of Italy v. MacGill, 93 Cal. App. 228, 269 Pac. 566 (1928).

${ }^{130}$ Cabifornia Nat'l Supply Co. v. Porter, 83 Cal. App. 758, 257 Pac. 161 (1927).

131 National Lumber Co. v. Whalley, 162 Cal. 224, 121 Pac. 729 (1912).

${ }^{132}$ Westwood Bldg. Materials Co. v. Valdez, 158 Cal. App. 2d 107, 322 P.2d 79 (1958). 133 Re-Bar Contractors v. City of Los Angeles, 219 Cal. App. 2d 134, 32 Cal. Rptr. 607 (1963).

134 Modesto Lumber Co. v. Wylde, 217 Cal. 421, 19 P.2d 238 (1933); Savage v. Nee, 212 Cal. App. 2d 417, 28 Cal. Rptr. 106 (1963). The fact that the sccondary improver is made a payee is notice to him that the co-payee does not lave authority to direct the final application of the funds. Modesto Lumber Co. v. Wylde, supra. Of course, if the maker consents to applying the funds to the discharge of debts which did not arise from work on the payor's property, then the improver does not lose his right to a lien. $C f$. Petaluma Bldg. Materials v. Foremost Properties, 180 Cal. App. 2d 83, 4 Cal. Rptr. 268 (1960). ${ }^{135}$ See Westwood Bldg. Materials Co. v. Valdez, 158 Cal. App. 2d 107, 322 P.2d 79
} 
Adequate protection from mechanics liens could be obtained through the use of written waivers with respect to a particular job, but the owner would liave to obtain a waiver from each improver entitled to a lien. For all practical purposes, this would mean everyone in some way connected with construction, including the unions. ${ }^{136}$ Even if this were possible it is improbable that all improvers would be willing to release hen rights unless provided with another form of security. Perhaps adequate protection could be obtained by paying everyone with joint checks, but this would be about the same as acting as a joint control agent.

\section{B. Joint Control}

A "joint control" agency is a business engaged in disbursing construction funds according to a predetermined schedule to those improvers entitled to payment. ${ }^{137}$ In essence a joint control agent is an escrow agent; he receives the construction funds and disburses them on a voucher system, obtaming a lien release with each payment. ${ }^{138}$ The function of the joint control agent includes an independent estimate of the cost of the proposed improvement, an evaluation of whether sufficient financing has been arranged, the development of an overall budget, and an inspection of the project periodically to assure that vouchers accurately reflect the state of affairs. ${ }^{139}$ In short, joint control performs many of the functions for which a prime contractor is engaged.

Joint control is intended to be the owner's and the lender's panacea, for in theory mechanics liens and stop notices will not be asserted because affirmative steps will have been taken to see that the project is financed adequately and that everyone is paid. Joint control can be quite useful to the lender who does not have the staff or expertise necessary to evaluate a project or to supervise disbursements. ${ }^{140}$ In practice the system is not without fault, lowever. ${ }^{141}$ Joint control offers protection from mechanics

(1958) (check issued by lenders). But cf. B. \& J. Constr. Co. v. Spacious Homes, 204 Cal. App. 2d 216, 22 Cal. Rptr. 41 (1962). An improver who is co-payee of a check from the owner or lender reasonably may be expected to understand that the money is intended to be applied toward payment of labor and materials for the related project. See Westwood Bldg. Materials Co. v. Valdez, supra.

136 See Cal. Code Crv. Proc. § 1182(d).

137 This particular industry seems still to be in the process of developing a name, for it is referred to by the state legislature as "joint control, by the public at large as builders" control, and classified in the California telephone directories as Builders' Construction Control Service." Comment, 16 Hasrmas L.J. 229 (1964) (footnotes omitted). The Comment is a detailed and reasonably objective analysis of the jomt control industry.

188 Comment, supra note 137 , at 230.

139 Id. at $230-31$.

$140 \mathrm{Id}$. at $231 \mathrm{n.11.}$

141 Hopkins, Stop Notices-Latest Report from the Battlefront, in CaLIForNIA LAND Titre Ass's, Proceedings Fifty-eighth Annual Conventron 62, 63 (1965). 
liens and stop notices only to the extent that no mistakes are made-an improver if unpaid still may exercise his statutory remedies. Presumably the owner would have a cause of action against the joint control agent for breach of contract or for negligence in the event of an error, but satisfying a judgment would require that the joint control agent have assets, which may not be the case. ${ }^{142}$

\section{Bonds}

Two types of bonds are relevant for protection against stop notices and mechanics liens:

Labor and Material Payment Bond: Guarantees payment of bills incurred by the bonded contractor for labor or materials furnished for the improvement. ${ }^{143}$

Performance Bond: Indemnifies the owner against loss resulting from the failure of the bonded contractor to complete the work in accordance with the plans and specifications. ${ }^{144}$

These two types of bonds are to be distinguished from the "indemnity bond," which is relevant after the lien has been asserted and which guarantees the payment of any suin that a mechanics lien claimant may recover on his claim and for his costs of suit. ${ }^{145}$ Variations on these types of bonds may be required under particular circumstances. ${ }^{140}$

Bonds are conditional instruments wlich, for purposes of underwriting, are divided into financial guarantees and nonfinancial guarantees. The obligation of a financial guarantee is discharged only by the payment of money. Collateral ordinarily is required for a bond of this nature since the obligation is certain. A nonfinancial guarantee may be discharged by performance. A labor and material payment bond and a performance bond are nonfinancial guarantees, as are inost bonds that a building contractor may need. Ultimately, the underwriter for a nonfinancial guarantee must satisfy himself as to the contractor's fidelity. ${ }^{\mathbf{1 4 7}}$

It is impossible to determine whether a given contractor is bondable without inquiring into the project for which the bond is desired. ${ }^{148} \mathrm{Al}$ though each surety has different underwriting standards, an underwriter

142 See Comment, supra note 137, at 237-42.

143 Mackali, Surety Underwriting Manuat 88-89 (1958); see Cat. Code Civ. Proc. \& 1185.1(c).

144 MACKAII, op. cit. supra note 143.

145 See Cat. Cgde Crv. Proc. § 1193.2.

146 See, e.g., CaI. Code Crv. Proc. § 1188.2.

147 Interview by the authors with Wilson Taylor, attorney for the Hartford Accident and Indemnity Company, San Francisco, July 30, 1965.

148 But see Comment, supra note 137, at 209: "It has heen estimated that as many as 30,000 of the 38,735 hicensed general contractors could not get bonds." 
is concerned with the amount of the bond and with the nature of the work of improvement. The amount of work to be done generally is the factor that limits bondability, although the underwriter also looks to the contractor's experience in the field wlich is the subject of the contract. As a rule of thumb, a contractor is eligible for a bond if his current assets exceed liabihties and unfinished work by ten per cent of the value of the work that will be undertaken. Stated another way, the himit of the bond which a contractor is likely to obtain is ten times the amount of his current assets after deducting the amount of liabilities and unfinished work. ${ }^{149} \mathrm{~A}$ contractor may be bondable for ten thousand dollars but not for one hundred thousand dollars, and may be bondable for the construction of a residence but not for the construction of a road.

A surety on a bond given pursuant to the mechanics hen or stop notice statutes is not exonerated from liability by changes in the building contract, modification of the terms of payment, rescission of the building contract, rescission of the bond, or conditions in the bond attempting to limit the rights of laborers or materialmen to recover..$^{150}$ A surety is not relieved of liability under a labor and material payment bond by any fraud practiced by any person other than the improver seeking to recover on the bond. ${ }^{151}$ Bonds are construed against the surety. ${ }^{152} \mathrm{~A}$ provision in the bond which attempts to shorten the period for suing on the bond to less than six nionths from the completion of the work of improvement is invalid. ${ }^{153} \mathrm{~A}$ provision in a labor and material payment bond which attempts to limit the period for the commencement of actions must allow at least six months from completion of the improvement and, for any limitation to be effective, the bond inust be recorded before commencement of work. ${ }^{154}$ If the bond is recorded before work is commenced on the improvement, however, an action may not be maintained on the bond unless a mechanics lien has been asserted or the surety was advised of the claim in writing within the period for filing mechanics liens. ${ }^{155}$ Any bond which meets the statutory requirements is conclusively presumed to be a good and sufficient bond if the surety is a corporation authorized to issue surety bonds in California. ${ }^{156}$

149 Interview with Wilson Taylor, supra note 147.

${ }^{100}$ Car. Code Crv. Proc. § 1200.1(a).

101 Ibid.

162 Cat. Code Clv. Proc. \& 1200.1(b).

153 CAT. Code CIV. Proc. \& 1200.1(c).

154 Ibid.

105 Cax. Code CIv. Proc. \& 1200.1(d). The notice must contain specified information, CAI. Code Crv. Proc. \& 1200.1(d), and may be served by registered mail addressed to locations specified by statute, CAx. Code Crv. Proc. $\$ 1200.1(\mathrm{e})$.

156 CaL. Code Crv. Proc. § 1200.1(f). 
A labor and material payment bond offers substantial protection. The aggregate recovery of mechanics lien claimants is limited to the unpaid balance of the contract price if the contract and the bond are recorded before work is commenced. ${ }^{157}$ The owner may proceed against the surety for indemnification to the amount of the bond even if it is not recorded. Stop notices may be ignored by both the owner and the lender if the labor and material payment bond and the original contract were recorded before work was commenced. ${ }^{158}$

\section{III}

\section{PROPOSED LEGISLATION}

A complete revision of the mechanics lien and stop notice statutes has been proposed by the Citizens' Advisory Committee to the Joint Judiciary Committees to the Assembly and Senate and was presented to the 1965 legislature as A.B. $1048 .^{159}$ The basic concepts are retained. Proposed changes are designed to keep relevant parties informed of the identity of improvers on the project and the extent of their contributions. As far as a lender is concerned, the impact of the proposals is not substantial, for the lender would still have to supervise the project closely. In the case of the owner building with his own funds, A.B. 1048 would afford greater protection than presently is enjoyed, for the owner would know his potential liability at an early date.

\section{A. Mechanics Liens}

A.B. 1048 would effect substantial modifications with respect to statutory agency and filing requirements.

\section{Statutory Agency}

A.B. 1048 would eliminate the concept of statutory agency, replacing it with a specific hist of persons entitled to a mechanics lien. All contractors, laborers, materialmen, architects, and engineers would have a lien upon the property. ${ }^{160}$ "Contractor" is defined to mean any independent contractor who furnishes labor or services at the site of the work of improvement. ${ }^{161}$ "Laborer" is defined as an employee of the

157 CAL. Code CIv. Proc. \& 1185.1(d).

158 CAL. CODE Crv. Proc. \$§ 1190.1 (c), (j).

159 Assembly Bill 1048 (1965) [hereinafter cited as A.B. 1048]. Citations to sections in A.B. 1048 refer to sections of the Civil Code that are proposed for enactment by the bill. 160 A.B. $1048, \S 3152$.

161 A.B. 1048, § 3111 . The definition of "contractor" is similar to that used in Theisen v. County of Los Angeles, 54 Cal. 2d 170, 352 P.2d 529, 5 Cal. Rptr. 161 (1960), discussed in part I, A, 1, a supra this article. Of no importance is the contractual relationship ordinarily used to distinguish a prime contractor from a secondary improver. Any improver is a "contractor" for hen purposes if he furnishes labor or services at the site of 
owner or of a contractor who furnishes labor or services at the site..$^{162}$ "Materialman" is any person who furnishes to the owner or to any contractor materials or equipment for the particular project in fact incorporated in the improvement but does not furnish any substantial labor at the site. ${ }^{163}$

Although lien rights would be given only to specified classes of improvers instead of everyone who contracts with a statutory agent, it easily could be as difficult to keep track of all members of the specified classes as it now is to discover the persons contracting with a statutory agent. The proposed cure for this difficulty is to be found in the elaborate notice requirements.

\section{Procedural Requirements for Perfecting the Lien}

A.B. 1048 would introduce substantially more paperwork into the construction business in an attempt to provide the owner and lender with information about the improvers engaged in construction and the extent of their contribution. There are two types of preliminary notices, the "notice of improvement" and the "notice of furnishing labor or materials." The notices are required only for an improvement involving an expenditure of more than one thousand dollars.

The notice of improvement would be given to improvers specified in the statutes by (a) the construction lender before the first advance on the loan, ${ }^{164}$ or (b) if there is no construction lender, the general contractor (if any) before initiating work. ${ }^{165}$ Each contractor who received a notice of improvement would have to serve a copy of the notice upon each subcontractor or materialman with whom he had contracted. ${ }^{168}$

Any secondary improver who had been served with a notice of improvement then would serve upon the owner and the general contractor, if any, a notice of furnishing labor or materials within twenty days after receiving the notice of iniprovement or after furnishing the first of the goods or services, whichever occurred later. ${ }^{167}$ The notice would also

the improvement. It appears that the proposed statutes require even less than does Theisen, since a "contractor" under A.B. 1048 does not need to have charge of a part of the work of improvement. Under the proposed statutes, however, a claimant is not entitled to a hen merely for contracting with a contractor. Theisen held that a claimant is entitled to a hen if he contracts with a statutory agent. The supplier in Theisen furnished materials to one who would be a materialman under A.B. 1048. He would not, therefore, be entitled to a lien under the proposed statutes.

162 A.B. 1048, § 3115.

163 A.B. 1048, § 3117.

104 A.B. 1048, § 3144.

105 A.B. $1048, \S 3145$.

100 A.B. 1048, § 3146.

167 A.B. $1048, \S 3155$. The only preliminary notice now required is the fifteen-day pre-lien notice. CaI. Code Crv. Proc. § 1193. 
have to be served on the lender in order for the improver to assert a stop notice. ${ }^{168}$

Giving the owner and the lender clear knowledge of potential liability seems in principle an improvement over the present system. The elaborate informational provisions, however, unquestionably would introduce greater quantities of records. Moreover, the proposed notice provisions would place on the owner the risk that the lender or prime contractor may fail to serve a notice of improvement. Unless served with a notice of improvement, the improvers would not be required to serve the notice of furnishing labor or materials as a condition to lien rights. The owner's property thus would be hypothecated to unknown claimants if the lender or prime contractor had failed to comply with the statutory requirements (although the lender would lose his priority). At least the owner should be expressly provided with a civil remedy against one who fails to serve a prescribed notice.

\section{Enforcing the Security Device}

The proposals retain in substance the present priorities rule, ${ }^{100}$ but with important differences. An encumbrance perfected before work commenced, securing an obligation incurred for a purpose other than financing construction, would be prior to mechanics liens to the extent of advances made before commencement. ${ }^{170}$ Apparently advances made after construction had begun would be subordinate to mechanics liens. An encumbrance recorded before work commenced and incurred to finance construction in whole or in part would be prior to mechanics hens to the extent of all advances, whether advances were obligatory or optional. ${ }^{171}$ The construction lender would lose his priority, however, if he had not performed his statutory duties. ${ }^{172}$ In addition, the construction lender could lose his priority as to a particular improver if the lender had made any advance on the construction loan without securing a waiver from the improver, the improver had sent a notice of furnishing of labor or materials to the lender, and the improver had furnished labor, services, equipment, or materials at the time of the advance. ${ }^{173}$

One interesting provision is that a general contractor could not collect from the owner any portion of the prime contract price until twenty days after completion of any project in which the contract price

108 A.B. $1048, \S 3185$.

169 A.B. 1048 , § 3165 .

170 A.B. $1048, \S 3166$.

171 A.B. $1048, \S 3167$.

172 Ibid.

173 Ibid. 
exceeded one thousand dollars but was no more than fifteen thousand dollars, unless a labor and material bond had been furnished and specified documents had been recorded. ${ }^{174}$

\section{B. Equitable Liens}

Apparently the draftsmen of the proposed statutes intend to eliminate the equitable lien remedy. ${ }^{175}$ Presumably A.B. 1048 contains ample protection for members of the construction industry, or else it is infirm. If the bill provides adequate protection, then it seems worthwhile to discard the equitable lien remedy and to simplify the mechanics hen field of security transactions.

\section{Stop Notices}

Under the proposal an improver served with a notice of improvement would be entitled to serve a stop notice on a lender only if the lender liad been served with a notice of furnishing labor or materials. ${ }^{176}$ Liability of the owner clearly would be himited to "the aggregate amount which becomes due to the prime contractor from the owner in accordance with the terms of their contract."

The lender served with a stop notice would be obligated to withhold

an amount equal to the lesser of (a) the amount of the claim stated in such stop notice or (b) the total original construction loan commitment of the construction lender minus the sum of all disbursements on account of the construction loan made prior to the receipt of such stop notice plus the aggregate of the claims stated in all stop notices received prior thereto. ${ }^{178}$

If the lender foreclosed its mortgage or deed of trust, its aggregate liability under stop notices would be limited to

(a) if the construction lender has made any advance on the construction loan without securing a waiver of any rights under this section executed by each claimant from whom the construction lender has received a notice of furnishing of labor or materials and who has furnished labor, services, equipment or materials at the time of such advance, the amount of the claims of all such stop notice claimants from whom such waivers were not obtained for all labor, services, equipment or materials furnished prior to the date of such advance, plus (b) the amount of the claims of all stop notice claimants for all labor, services, equipment or materials furnished after the date of the

174 A.B. 1048, § 3147 .

175 See A.B. $1048, \S 3199$.

176 A.B. 1048 , § 3185.

177 A.B. 1048, § 3187.

178 A.B. 1048, § 3189. 
last advance on the construction loan prior to the date of recording the notice of default. ${ }^{179}$

In defining the "fund" from which the lender must withhold, A.B. 1048 speaks of the "total original construction loan commitment of the construction lender."180 Although this phrase is not defined, the provision appears to require that the entire proceeds of a loan be available to stop notice claimants despite a contrary himitation in the payment arrangement between the lender and borrower. It appears, therefore, that A.B. 1048 incorporates the $A-1$ Door decision as to stop notice claims against undisbursed construction funds. ${ }^{181}$

170 A.B. $1048, \S 3190$.

180 A.B. $1048, \S 3189$.

181 See part I, C, 2 supra this article. 


\section{California Law Review}

\begin{tabular}{lll}
\hline \hline Vor. 54 & MARCH 1966 & No. 1 \\
\hline \hline
\end{tabular}

\section{BOARD OF EDITORS}

Micenaet E. ThaAr

Editor-in-Chief

A. JAMES ROBERTS III

Managing Editor

Fredertce InNes fox Article Editor

ROBERT W. STEDMAN Article Editor

Richard L. Jaeger

Research Editor

JoHn Conrad Fossuar

Book Review Editor

LEE J. SCLAR

Associate Editor
D. KEITH BIITER

Head Note \& Comment Editor

Gordon L. Graitam

Note \& Comment Editor

Gerald E. Mulzen

Note \& Comment Editor

Douglas R. Reynotds

Note \& Comment Editor

Diana S. Stoppeuto

Note \& Comment Editor

Research Board

Dennis M. Eagan

\section{Donazd Bodex}

LARRY BRAXTON DERT

ROBERT H. BERGER

JeRrY J. BERASAN

ROBERT ALAN BIUNS

Alas G. Carlton

Patol Elliot Crost

Geores Custaming

TOM A. Dowse

Davio B. Frohomatayer

DANIEL S. Frost

Barbara Brudno Gardner
THEOdore J. ENGLAND

\section{Associates}

Loyd Paxton Derby

KENNEY F. HEGLAND

EDWTN N. LOWE, JR.

\section{Candidates}

KeNNETE A. GoldMaA

Donato S. Greenberg

Stephen H. GreenLeat

MARTIN E. HARBAND

ALEXANDER M. HEHMIEYER

Robert Cart Herr

DALLAS HoLMass

STEVEN M. KTPPERMAN

Davm ATAN LETPZTGER

EdMund R. Manwetr

MarjorIE Devereux

Administrative Assistant
RODOLFO MONTEJANO

Citfrord K. Thomipson, Jr. David M. WIIsoN

Richard S. Platz NordaA ERNest Reitz CArL J. Senekgr II Myron G. SUgarman Sandra Terztan Gary E. Thacher TRACY A. WESTEN Standey H. Wirliams Chardes Wilson KeIIX C. WoOster 